\title{
Evidence of an endogenous lectin receptor in seeds of the legume Cratylia floribunda
}

\author{
Márcio Viana Ramos $^{1 *}$, Liezelotte Rezende Bomfim ${ }^{1}$, Glaís de Paiva Bandeira ${ }^{1}$ and Henri Debray ${ }^{2}$ \\ ${ }^{1}$ Departamento de Bioquímica e Biologia Molecular, Universidade Federal do Ceará, Campus do Pici, CP 6033, CEP 60451-970, \\ Fortaleza, CE, Brasil; ' ${ }^{2}$ Université des Sciences et Technologies de Lille, Laboratoire de Chimie Biologique et UMR $n^{\circ} .8576$ du \\ CNRS, 59655 Villeneuve D’Ascq Cedex, France.*Corresponding author: vramos@ufc.br \\ Received: 7/10/2002, Accepted: 21/11/2002
}

Cratylia floribunda seeds were ground and the clean crude saline extract was fractionated into albumin, globulin, prolamin, acidic and basic glutelin protein fractions. These protein fractions were examined for the presence of an endogenous lectin receptor by SDS-polyacrylamide gel electrophoresis, Western blot, affinity chromatography on a Sepharose 4BCratylia floribunda (CFL) lectin column and kinetic analysis in real time by surface plasmon resonance (SPR). Prolamin was the richest protein fraction although very poor in haemagglutinating activity. Basic glutelin was far the less interesting fraction for lectin activity and protein content, even though this fraction contains considerable amounts of carbohydrates. Lectin was present in all protein fractions as estimated by haemagglutinating assays but basic glutelins were almost devoid of lectin activity. Except for prolamins, protein bands were detected by SDS-PAGE in all other fractions. Western blot using digoxigenin labelled Con A revealed a single band in the albumin, globulin, acidic and basic glutelin fractions, which specifically interacted with ConA. This band migrated exactly at the same position in such fractions and seemed to be more important in the globulins. Affinity chromatography of the protein fractions on a Sepharose-CFL column yielded a peak, which was only recovered after elution with acidic buffered solution or with an $\alpha$-D-mannose solution, the monosaccharide recognized by the lectin. These results were fully corroborated by real time interaction of immobilized CFL with the different soluble protein fractions suggesting the presence of a lectin receptor within albumins, globulins and basic glutelins. As a whole, the results suggest that the lectin from Cratylia floribunda recognizes a soluble endogenous glycosylated receptor through an interaction mediated by its carbohydrate-binding site.

Key words: protein-carbohydrate interaction, surface plasmon resonance, Western blot.

Evidências de um receptor endógeno de lectina em sementes da leguminosa Cratylia floribunda: Sementes de Cratylia floribunda foram moídas e o seu extrato salino solúvel foi fracionado para obter as frações protéicas albumina, globulina, prolamina, glutelina ácida e glutelina básica. Essas frações protéicas foram examinadas quanto à presença de algum receptor endógeno para a lectina da semente através de eletroforese em gel de poliacrilamida em presença de SDS, Western blot, cromatografia de afinidade em coluna de Sepharose 4B contendo a lectina de Cratylia floribunda (CFL) imobilizada e análise cinética em tempo real baseada em ressonância plasmônica de superfície. A fração prolamina foi a mais rica em proteínas, embora pobre em atividade hemaglutinante. Glutelina básica foi a fração menos interessante quanto ao teor protéico e atividade hemaglutinante, embora tenha considerável teor de carboidratos. A lectina estava presente em todas as frações protéicas de acordo com os testes de atividade hemaglutinante, porém a fração de glutelinas básicas quase não apresentou atividade. Exceto as prolaminas, bandas protéicas foram detectadas em todas as outras frações protéicas por SDS-PAGE. A técnica de Western blot usando Con-A conjugada à digoxigenina revelou uma única banda nas frações albumina, globulina, prolamina, glutelinas ácidas e básicas, que interagiu especificamente com a ConA. Esta banda apresentou exatamente a mesma localização nessas frações e pareceu mais evidente nas globulinas. Cromatografia de afinidade das frações protéicas sobre a coluna de Sepharose 4B-CFL produziu um pico que foi eluído da coluna apenas após a adição de tampão glicina ou solução de um açúcar inibidor da lectina ( $\alpha$-D-manose). Esses resultados foram completamente confirmados através dos estudos de interação em tempo real das mesmas frações com a lectina CFL imobilizada, sugerindo também a presença de um receptor endógeno nas frações albumina, globulina e glutelinas básicas. Como um todo, os resultados sugerem que a lectina de sementes de Cratylia floribunda reconhece um receptor específico e que essa interação deveria ser mediada pelo sítio de interação a carboidratos.

Palavras-chave: interação proteína-carboidrato, ressonância plasmônica de superfície, Western blot. 


\section{INTRODUCTION}

Lectins are carbohydrate-binding proteins widely distributed in nature (Van Damme et al., 1998; Rudiger et al., 2000). Their ability to specifically recognize and reversibly bind to soluble or cell bound complex carbohydrate structures make them special candidates to play different roles in many biological processes such as cell to cell interaction, ligand-receptor signalizing or cellular activation, among other important biological events (Wu et al., 1995; Gorocica et al., 1998; Sáez et al., 1999). However, the precise functions of plant lectins are still depending on more conclusive experimental evidence. Although many reports focusing on their role in nature have given important insights in this matter, endogenous lectin receptors in plants have not been fully described or characterized. Most of the obtained results suggest that plant lectins may take part in the plant defence system together with chitinase, glucosidase and protease inhibitors (Etzler, 1998). Legume lectins are also expected to participate in specific symbiosis involving roots and bacteria Rhizobia (Diaz et al., 1989; Naeem et al., 2001). Together, these hypotheses support the idea that the functions of plant lectins are addressed to foreign organisms and thus the hypothesis for the occurrence of endogenous receptors is currently unattractive (Peumans et al., 2000).

In the 1980 s and early 1990 s, a German group devoted some attention to the possible occurrence of endogenous lectin binding compounds following the idea that legume lectins which are vacuolar proteins stored in the protein bodies in seeds, could be the natural ligands for other glycocompounds located in the protein bodies, including their membranes (Einhoff et al., 1986; Rudiger and Schercher, 1993; Gers-Barlag et al., 1993; Schercher and Rudiger, 1994; Wenzel and Rudiger, 1995). Although their results did point to the interaction of the assayed lectins with some endogenous compounds, differences in the carbohydrate binding specificity of the lectins and evidence of a complex of lectins and stored proteins or membrane components mediated by ionic strength prevented more conclusive results. Furthermore, no endogenous ligand was isolated or characterized. Despite these results, it is of great importance to document the interaction of lectins with any endogenous compound, as it will certainly contribute to clarify the role of these proteins in plants.

Cratylia floribunda is a legume tree whose seeds possess a Con A-like lectin (Oliveira et al., 1991). ConA, the lectin isolated from Canavalia ensiformis seeds and Cratylia floribunda lectin, named CFL, can be isolated in a single step by affinity chromatography on a Sephadex G-50 matrix and share many biochemical and structural characteristics including their identical carbohydratebinding specificity (Ramos et al., 1996a, b; Dam et al., 1998, 2000). In this report we present evidence for the presence of a Cratylia floribunda lectin (CFL) glycosylated receptor within the seed flour protein fractions, which may be recognized by the Cratylia floribunda lectin and by Con A, the lectin from Canavalia ensiformis seeds.

\section{MATERIAL AND METHODS}

Lectin isolation and immobilisation: Cratylia floribunda seeds were collected in the state of Ceará, Brazil. The purified lectin was obtained by affinity chromatography on a Sephadex G-50 column as described by Oliveira et al. (1991). Material purity was checked by $12.5 \%$ SDSPAGE according to Laemmli (1970). The purified lectin (30 mg) was coupled to CNBr-activated Sepharose 4B (Pharmacia) (10 $\mathrm{mL})$ according to the procedure described by March et al. (1974). After immobilization, the amount of soluble lectin still remaining in the supernatant (uncoupled) was estimated by spectroscopy at $280 \mathrm{~nm}$ as $4.02 \mathrm{mg}$. From the difference, the amount of bound lectin was considered to be close to $2.5 \mathrm{mg}$ per $\mathrm{mL}$ of gel.

Preparation of protein fractions from the crude extract: Hulled seeds were ground and the fine flour was suspended in $500 \mathrm{mM} \mathrm{NaCl}(1: 10, \mathrm{w} / \mathrm{v})$ for $2 \mathrm{~h}$ under shaking, followed by centrifugation at $20.000 \mathrm{~g}_{\mathrm{n}}$ at $4{ }^{\circ} \mathrm{C}$ for $20 \mathrm{~min}$. The pellet was extracted again under the same conditions and the new supernatant joined to the previous one. This fraction, named crude extract, was dialysed against distilled water and centrifuged again under the same conditions. The supernatant, named albumins, was lyophilized. The precipitated fraction was dissolved in $500 \mathrm{mM} \mathrm{NaCl}$, followed by dialyse against water and lyophilized. This fraction was named globulins. Prolamins were obtained by extraction with $70 \%(\mathrm{v} / \mathrm{v})$ ethanol of the pellet obtained after centrifugation of the crude extract. The new fraction was centrifuged as above and the supernatant submitted to dialyse and lyophilization. The new pellet was then extracted with $100 \mathrm{mM} \mathrm{HCl}$ and centrifuged. The supernatant was named acidic glutelins and was lyophilized after dialysis. Finally, the pellet resulting from this 
centrifugation was suspended and extracted in $100 \mathrm{mM}$ $\mathrm{NaOH}$ and centrifuged. The new supernatant was dialysed and lyophilized and named basic glutelins. The pellet was discarded.

Haemagglutinating activity: The haemagglutinating activity of protein fractions was determined according to Ramos et al. (1996a,b) using $2 \%$ (v/v) rabbit erythrocyte cell suspension in $150 \mathrm{mM} \mathrm{NaCl}$. Analyses were done in duplicate and haemagglutinating potency was expressed as haemagglutinating units (HU).

Protein estimation: Protein in soluble fractions was estimated by the Bradford (1976) method using bovine serum albumin as standard.

Carbohydrate detection: The presence of carbohydrate in fractions was estimated according to Dubois et al. (1956) using glucose as a standard.

Gel electrophoresis: The purified CFL and protein fractions obtained by fractioning the crude saline extract of the Cratylia floribunda seed flour were examined by $15 \%$ polyacrylamide gel electrophoresis under denaturing and reduction conditions in the presence of sodium dodecyl sulphate (SDS) and 2-mercaptoethanol according to Laemmli (1970). Samples of albumins, globulins, acidic and basic glutelins ( $\left.2 \mathrm{mg} \cdot \mathrm{mL}^{-1}\right)$, prolamins (4 mg.mL $\left.{ }^{-1}\right)$ and lectin $\left(1 \mathrm{mg} \cdot \mathrm{mL}^{-1}\right)$ were treated with tris buffer $\mathrm{pH} 6.8$ containing $2 \% \operatorname{SDS}$ and $5 \% \beta$-mercaptoethanol at $100{ }^{\circ} \mathrm{C}$ for $4 \mathrm{~min}$. and analysed. Run was performed at $40 \mathrm{~mA}$ at room temperature. Gels were stained with coomassie brilliant blue solution in water: acetic acid: methanol $(8: 1: 3.5, \mathrm{v} / \mathrm{v} / \mathrm{v})$ and destained with the same solution without the dye or used for Western blotting analysis.

Western blot: Polyacrylamide gel electrophoresis of CFL and protein fractions prepared as above, was electrotransfered on a nitrocellulose membrane (Life Technologies, USA) at $40 \mathrm{mV}$ overnight at $4{ }^{\circ} \mathrm{C}$. The remaining gel was further stained by coomassie brilliant blue solution to confirm the transfer of all the protein bands onto the nitrocellulose membrane. The nitrocelullose membrane was revealed with $0.2 \%$ ponceau $\mathrm{S}$ in $3 \%$ trifluoroacetic acid (v/v) and destained with PBS. The nitrocellulose membrane was blocked with $2 \%$ polyvinylpyrrolidone for $1 \mathrm{~h}$ at room temperature followed by five washes with PBS. The membrane was then incubated with a solution of digoxigenin-labelled ConA (Calbiochem, USA) in PBS for $3 \mathrm{~h}$ at room temperature and further washed with PBS. Then incubation with rabbit anti-digoxigenin antibodies coupled to horseradish peroxidase (Calbiochem, USA) was performed for $1 \mathrm{~h}$ followed by washing with PBS. The membrane was revealed by incubation with $15 \mathrm{~mL}$ of diaminobenzidine (Calbiochem, USA) in urea $/ \mathrm{H}_{2} \mathrm{O}_{2}$ solution until the appearance of bands.

Affinity chromatography on a Cratylia floribunda lectinSepharose column: To perform the affinity chromatography of albumin, globulin, prolamin and acidic and basic glutelin fractions on the lectin column, the lyophilized fractions solubilized in $150 \mathrm{mM} \mathrm{NaCl}\left(1 \mathrm{mg} \cdot \mathrm{mL}^{-1}\right)$ were applied to the column and eluted first in $150 \mathrm{mM} \mathrm{NaCl}$ and then with $50 \mathrm{mM}$ glycine-HCl buffer $\mathrm{pH} 2.6$ in $150 \mathrm{mM} \mathrm{NaCl}$. Fractions of $1.5 \mathrm{~mL}$ were recovered using a flow rate of $10 \mathrm{~mL} \cdot \mathrm{h}^{-1}$. Absorbance of fractions was followed at 280 nm with a Ultrospec 1000 spectrophotometer (Pharmacia).

Kinetic interaction: Kinetic studies of soluble protein fractions with immobilized CFL were measured in real time based on surface plasmon resonance technology using a BiaCore 3000 instrument (Pharmacia Biosensor) (Zeng et al., 1998; Satoh and Matsumoto, 1999; Canziani et al., 1999). The purified CFL $\left(200 \mu \mathrm{g} \cdot \mathrm{mL}^{-1}\right)$ was bound to the dextran layer of the CM-5 sensor chip using the amino coupling kit following the manufacturer's instructions. For coupling, the lectin $\left(1 \mathrm{mg} \cdot \mathrm{mL}^{-1}\right)$ was dissolved in $10 \mathrm{mM}$ acetate buffer $\mathrm{pH}$ 4.0. Non-reacting remaining groups were blocked with ethanolamine. The protein fractions (1 $\mathrm{mg} \cdot \mathrm{mL}^{-1}$ ) (albumins, globulins, prolamins, acidic and basic glutelins) were injected on the cell surface of the sensor at a flow rate of $5 \mu 1 . \mathrm{min}^{-1}$ for $300 \mathrm{~s}$ (association phase) and allowed to dissociate in equal time in HBS buffer $(10 \mathrm{mM}$ HEPES pH 7.4, 150 mM NaCl, 3 mM EDTA, 0.005 \% (v/ v) surfactant P20, BiaCore). Interaction intensity was considered as the difference between values of arbitrary resonance units (RU) at the moment of injection and the beginning and the end of the dissociation phase reducing the bulk contribution caused by passage of the sample under the cell surface. For inhibition assays, $100 \mathrm{mM} \alpha-$ methylmannoside was injected at the end of dissociation phase and allowed to interact for $300 \mathrm{~s}$, followed by the running buffer (HBS). All experiments were conducted at 
$25{ }^{\circ} \mathrm{C}$. Flow cell regeneration was achieved by two successive injections of $10 \mathrm{mM} \mathrm{HCl}$ and $10 \mathrm{mM} \mathrm{NaOH}$ to remove the remaining material still bound to the sensor surface. To confirm performance of lectin immobilization, interaction with the glycoprotein soybean agglutinin, known to be a very potent ligand to CFL and inhibition of this interaction was performed under the same conditions.

\section{RESULTS}

Protein fractions obtained from the crude saline extract of the Cratylia floribunda seed flour were characterized for protein and carbohydrate content and analysed by polyacrylamide gel electrophoresis under dissociating conditions. These fractions were also examined for interaction with the purified seed lectin CFL by affinity chromatography on a Cratylia floribunda lectin-Sepharose column and kinetic analysis based in surface plasmon resonance technology (RPS).

Table 1 summarises the protein content of the albumin, globulin, prolamin, acidic and basic glutelin fractions. Prolamin was the richest protein fraction but very poor in haemagglutinating activity. Basic glutelin was the less interesting fraction for lectin activity and protein content, even though it contained a considerable amount of carbohydrates. Lectin was present in all protein fractions as estimated by haemagglutinating assays but basic glutelins were almost devoid of lectin activity. The presence of CFL in the fractions was further confirmed by SDS-PAGE (figure 1). The alpha chain and both beta and gamma fragments of CFL (Ramos et al., 1996a) were present as the main protein band in the albumin fraction and also as an important component of globulins, acidic and basic glutelins. In spite of the amount of protein estimated by the Bradford (1976) method in the prolamin fraction, no protein bands were detected in this fraction by SDS-PAGE. This fraction was strongly coloured and protein content might be over estimated by the interference of organic compounds other than proteins. The same phenomenon seemed to occur when this fraction was examined at $280 \mathrm{~nm}$ after affinity chromatography.

Affinity chromatography profiles of the protein fractions on the Cratylia floribunda lectin-Sepharose column are shown in figure 2. After washing the column with the starting solution (150 mM NaCl), glycine-HCl buffer was used to elute possible lectin ligands from the column. Intensity of absorbances at $280 \mathrm{~nm}$ during washing of the column matched exactly with the protein content previously determined by the Bradford method (table 1). It is noteworthy that the prolamin absorbance peak confirmed the estimation of protein content within the whole fraction. Nevertheless, it did not show any protein band stained by coomassie in SDS-PAGE (figure 1). Passage of glycine buffer through the column yielded changes in albumins, globulins and acidic glutelins absorbance, giving rise to a small peak while no peak was obtained from the prolamin and basic glutelin fractions (figure 2). The fractions recovered after the addition of glycine- $\mathrm{HCl}$ buffered solution were assayed for carbohydrate by the Dubois (1956) method but this method was not sensitive enough to detect carbohydrates in the fractions.

Table 1. Protein and carbohydrate contents and haemagglutinating activity of Cratylia floribunda protein fractions.

\begin{tabular}{lccc}
\hline $\begin{array}{l}\text { Protein } \\
\text { fractions }\end{array}$ & $\begin{array}{c}\text { Protein } \\
\left(\mu \mathrm{g} . \mathrm{mL}^{-1}\right)\end{array}$ & $\begin{array}{c}\text { Carbohydrate } \\
\left(\mu \mathrm{g} . \mathrm{mL}^{-1}\right)\end{array}$ & $\begin{array}{c}\text { Lectin activity } \\
(\mathrm{U} . \mathrm{H} .)\end{array}$ \\
\hline Albumin & 348,50 & 25.56 & 256 \\
Prolamin & 411.50 & 162.60 & 64 \\
Globulin & 149.95 & 16.14 & 256 \\
Acidic glutelin & 149.00 & 30.80 & 64 \\
Basic glutelin & 26.00 & 20.80 & 2 \\
\hline
\end{tabular}

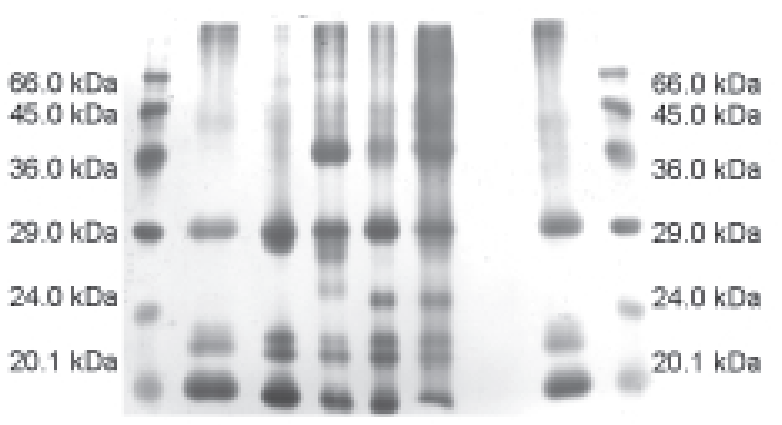

Figure 1. SDS-PAGE of the purified CFL lectin and protein fractions. From left to right: molecular mass markers, CFL, albumins, globulins, acidic glutelins, basic glutelins, prolamins, CFL and molecular mass markers (Bovine serum albumin $66 \mathrm{KDa}$, Ovalbumin $45 \mathrm{KDa}$, Glyceraldehyde-3- phosphate dehydrogenase $36 \mathrm{KDa}$, Carbonic anhydrase $29 \mathrm{KDa}$, Trypsinogen $24 \mathrm{KDa}$, Trypsin inhibitor 20,1 KDa, alpha-Lactalbumin 14,2 KDa). 


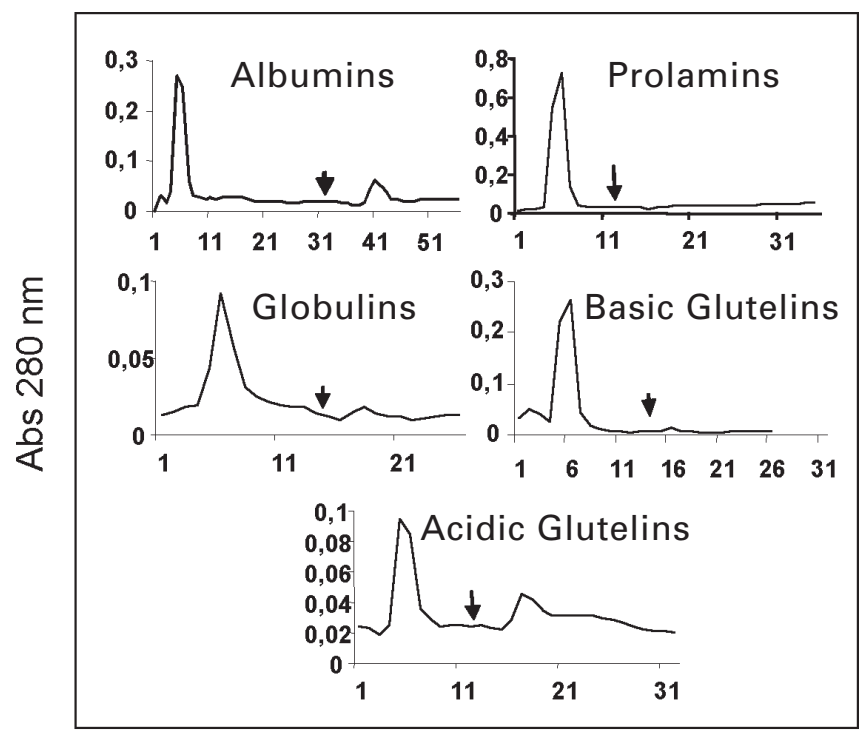

Fractions

Figure 2. Affinity chromatography of the protein fractions from the C. floribunda seed flour on a Sepharose 4B-Cratylia floribunda lectin column. Samples: $1 \mathrm{~mL}$; fraction size: $1.5 \mathrm{~mL}$; flow rate: $10 \mathrm{~mL} \cdot \mathrm{h}^{-1}$. Arrows indicate the elution with $50 \mathrm{mM}$ glycine- $\mathrm{HCl}$ buffer $\mathrm{pH}$ 2.6 in $150 \mathrm{mM} \mathrm{NaCl}$ or with $100 \mathrm{mM} \alpha$-D-mannose for albumins.

Western blot analysis was a good strategy to search for lectin interacting material in the fractions. For this purpose, digoxigenin-labelled ConA was chosen. ConA-digoxigenin was used because it is commercially available and because ConA has very similar carbohydrate-binding specificity to CFL (Ramos et al., 1996a,b). Accordingly, ConA and CFL recognize the same carbohydrate structures already tested by different methods although the magnitude of interaction may vary for more complex carbohydrate structures (Dam et al., 1998; Ramos et al., 2002). According to Western blot analysis, ConA recognized only a high molecular mass component in all protein fractions from the Cratylia floribunda seed flour. Furthermore, it appears exactly at the same position in all protein fractions (figure 3 ). The band was more evident in the globulin fraction but was also present to a lesser extent in albumin, acidic and basic glutelin and prolamin fractions. No other additional bands were detected within the protein fractions, CFL or in the lines corresponding to the molecular mass markers (see figure 3). This supports the hypothesis that binding of ConA was carbohydrate specific. These results support those obtained by affinity chromatography of CFL with albumins, globulins and acidic glutelins even if they differ for prolamin and basic glutelin fractions. Positive results in Western blotting obtained with the latter fractions may be due to the higher sensitivity of the method used rather than in differences in the specificity of CFL and ConA.

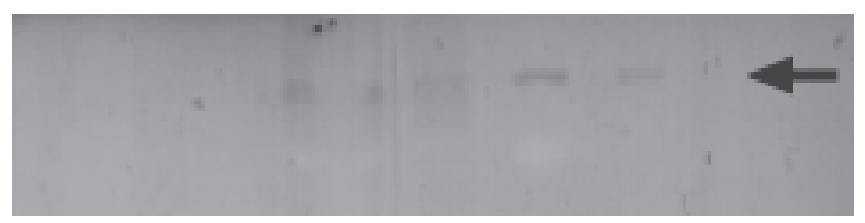

Figure 3. Developing with digoxigenin-labelled ConA of the Western blot of SDS-PAGE shown in figure 1. Left to right: Molecular mass markers, CFL, prolamins, basic glutelins, acidic glutelins, globulins, albumins, CFL and molecular mass markers. No bands are visible in CFL or molecular mass markers lanes.

In order to extend the analysis of lectin binding to protein fractions, the kinetic interaction of immobilized CFL and soluble proteins from albumin, globulin, prolamin and acidic and basic glutelin fractions was measured in real time by surface plasmon resonance technology. First, CFL was covalently bound to a carboxymethyl dextran layer of the sensor ship. Kinetic analysis of the interaction between CFL and soluble soybean agglutinin was performed to test the lectin activity (figure 4A). CFL, which is known to interact strongly with high mannose oligosaccharides, bound tightly to soybean, a glycoprotein possessing a high mannose oligosaccharide (Dorland et al., 1981) (curve a) and this interaction was partially inhibited by the presence of $100 \mathrm{mM} \alpha$-methylmannoside (curve $b$ ). Kinetic analysis of individual protein fractions provided interesting results. No interaction was observed between CFL and prolamin or basic glutelin fractions while albumin, globulin and acidic glutelin fractions were more or less recognized by the lectin (figure 4B). Profiles yielded with prolamins and basic glutelins were typical of a lack of interaction. Curves obtained with albumin, globulin and acidic glutelins are typical of a weak interaction and this could be explained by a very low concentration of the soluble ligand in the assayed samples. During the association phase, increase in resonance units occurs progressively while in the dissociation phase, decrease in resonance units is more expressive. Despite the performance of the SPR methodology, results obtained by Western blot analysis were not reproduced with the prolamin and basic glutelin fractions. This may be interpreted by differences of sensitivity in the two approaches. The sensitivity of the Western blot analysis 
was improved by washing of non-specific ligands. RPS is a very sensitive method for bio-interaction analysis but the dissociation is highly favoured if ligand concentration is not ideal or if affinity is not strong. Furthermore, prolonging the dissociation phase with running buffer induces natural dissociation and thus does not allow inhibition assays to be performed. Accordingly, inhibition of the interaction of CFL with albumin fraction with 100 $\mathrm{mM} \alpha$-methylmannoside did not change the kinetic profile at all (figure 4C). It should be noted that kinetic interaction results based in surface plasmon resonance corroborated with those of affinity chromatography, where prolamin and basic glutelin fractions did not bind to immobilized CFL while albumin, globulin and acidic glutelin proteins did.

Because many strategies have failed to detect endogenous lectin receptors, it is expected that lectin ligands should occur at very low concentrations if it is a soluble compound. Detection of such molecules based in their lectin reactivity is heavily dependent on the sensitivity of the method used. In addition to well-explored affinity chromatography principles, combined Western blotting and RPS analysis of the protein fractions were used successfully here. Kinetic curves for albumin, globulin and acidic glutelin fractions did seem to reflect the presence of a lectin ligand. Even at very low concentration, some soluble component in these fractions seems to be an endogenous CFL ligand. Accordingly, dissociation is very fast and addition of inhibiting sugar could not improve dissociation (figure 4C). It should be expected that crude extract did not work as well as protein fractions because the later represent more purified preparations. This is why the crude extract was first fractionated before analysis. Alltogether, results from SDSPAGE, Western blotting, affinity chromatography and RPS analysis emphasized the presence of an endogenous lectin receptor within the Cratylia floribunda seed.

\section{DISCUSSION}

Despite the great number of reports describing many biochemical and structural aspect of plant lectins and their increasing utilization as biotechnological tools, many questions concerning their role in the plant kingdom still remain open. As a starting point, lectin distribution in plants and their ultra structural localization addressed the first hypothesis regarding their functions. Accordingly, earlier investigations explored the role of lectins in plant defence against seed predators (insects or fungi) or during seedling

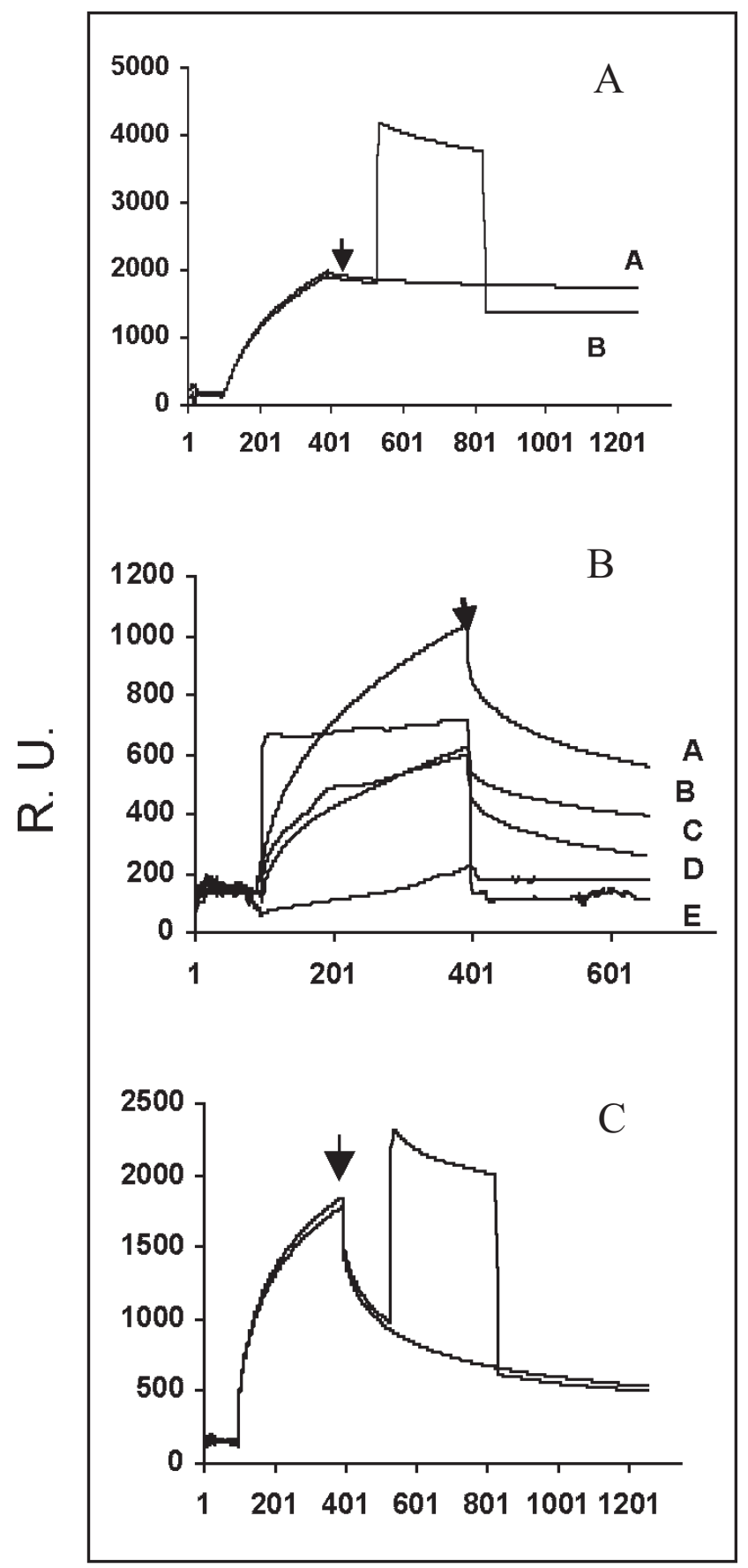

\section{Time (s)}

Figure 4. Kinetic interaction measured in real time of immobilized CFL with the different protein fractions. A: CFLsoybean interaction (curve a) and inhibition of the interaction with $100 \mathrm{mM} \alpha$-methylmannoside (curve b). B: interaction of CFL with albumins (curve a), globulins (curve b), acidic glutelins (curve c), prolamins (curve d) and basic glutelins (curve e). C: interaction of CFL and albumins and inhibition of the interaction with $100 \mathrm{mM}$ $\alpha$-methylmannoside. Arrows indicate the end of association phase and addition of the sugar in the panels A and C. 
development (Etzler, 1998; Naeem et al., 2001). Legumes are still considered as the most important source of lectins. In seeds, considerable amounts of lectin accumulates in the protein bodies forming a package together with wellcharacterized storage proteins, although lectins are also found in the root hair as in pea plants (Diaz et al., 1989). Otherwise, the carbohydrate binding specificity and the molecular basis of lectin-carbohydrate interaction are now well established mainly for legume lectins (Van Damme et al., 1998). The great gap in lectin research is the detection and characterization of endogenous receptors. As a consequence, some authors have defended the hypothesis that higher plants developed structurally different motifs to recognize foreign glycans based on lectin binding properties (Peumans et al., 2000). References to research on endogenous lectin binding partners are rare in the literature. As a whole, they provided evidences for the interaction of seed lectins with some components of the protein body membranes or with the storage proteins themselves. The fact that these interactions seem to be mediated by ionic strength more than governed by the carbohydrate-binding site of the lectins or by both interactions deserves more detailed investigations.

We have investigated here the presence of an endogenous receptor for the Cratylia floribunda seed lectin. It should contribute to extend results showing that lectins may recognize endogenous compounds through interactions either mediated by their carbohydrate-binding site or by the whole molecule. Assuming that the researched ligand(s) occur(s) at very low concentration, the crude saline extract of the seed flour was first fractionated into albumin, globulin, prolamin and acidic and basic glutelin fractions. As presented here, CFL seemed to bind to some components of the protein fractions. Albumin, globulin and acidic glutelin fractions were shown to contain protein(s) cross reacting with immobilized CFL as explored by affinity chromatography. Displacement of the bound material by changing the $\mathrm{pH}$ conditions in affinity chromatography does not clarify whether this interaction is mediated by the carbohydrate binding-site, sustained by salt bridges between the lectin and the protein fraction, or by both mechanisms. However, it is worth noting that the experiments were conducted in $150 \mathrm{mM} \mathrm{NaCl}$ solution, which avoids or strongly minimizes electrostatic effects. Furthermore, when eluted with $100 \mathrm{mM}$ mannose instead of the glycine- $\mathrm{HCl}$ buffer, albumin fraction was shown to yield a similar absorbance peak (data not shown). Thus, one can assume that interaction of a minor component of this fraction with the lectin column is carbohydratemediated.

The nature of the lectin interaction with endogenous molecules is obviously of great interest as these proteins are grouped together based in their most prominent characteristic that is the ability to specifically bind carbohydrates. Evidences that plant lectins interact with classical storage proteins or membrane components of the protein bodies by ionic forces as shown by Rudiger and co-workers could reflect the highly compacted structure of the protein bodies. This would induce natural contacts among the stored proteins, rather than represent a specific characteristic of lectins or the fact that the lectins exist to accomplish this role. Indeed, results from Rudiger and coworkers, cited previously, gave insights into the idea that legume lectins do participate in the maintenance of the protein bodies membrane and most importantly that the assayed lectins were able to bind to some endogeneous glycoconjugate(s), even if ionic strength also seemed to be involved. Furthermore it is not plausible to consider that lectins could be an extraneous molecule in this subcellular structure. Chemical affinity among proteins stored in protein bodies ought to be a sine qua non condition to make possible the package of the organelle.

The aim of our work was to get evidence that plant lectins have endogenous receptor(s) for their carbohydratebinding site. To accomplish this goal, Cratylia floribunda seed flour was investigated because it possesses a wellcharacterized glucose/mannose binding lectin. The lectin was shown to bind to different protein fractions prepared from the crude saline seed flour extract and the closely related lectin ConA was shown also to bind to the same soluble molecule(s) present in the C. floribunda protein fractions by Western blot analysis. In summary, the results presented here give evidence on the interaction of the seed lectin from Cratylia floribunda with soluble molecules present in the protein fractions obtained from the seed flour and show that this interaction may be mediated by the lectin carbohydrate-binding site.

Acknowledgements: The authors thank IFS (MVR), FUNCAP, CNPq, CAPES/COFECUB program for the financial support. We are indebted to the Service Commun d'Imagerie Cellulaire de l'Université de Lille II for providing access to the BiaCore Apparatus. 


\section{REFERENCES}

Bradford MM (1976) A rapid and sensitive method for the quantification of microgram quantities of protein utilizing the principle of protein-dye binding. Anal. Biochem. $72: 248-254$.

Canziani G, Zhang W, Cines D, Rux A, Willis S, Cohen, G, Eisenberg, R, Chaiken, I (1999) Exploring biomolecular recognition using optical biosensors. Methods 19:253-259.

Dam TK, Cavada BS, Grangeiro TB, Santos CF, Sousa FAM, Oscarson S, Brewer CF (1998) Diocleinae lectins are a group of proteins with conserved binding sites for the core trimannoside of asparagine-linked oligosaccharides and differential specificities for complex carbohydrates. J. Biol. Chem. 273:12082-12088.

Dam TK, Cavada BS, Grangeiro TB, Santos CF, Ceccatto VM, Sousa FAM, Oscarson S, Brewer CF (2000) Thermodynamic binding studies of legume lectins from Diocleinae subtribe to deoxy analogs of the trimannoside core of asparagine-linked oligosaccharides. J. Biol. Chem. 275: 16119-16126.

Diaz CL, Melchers LS, Hooykaas OJJ, Lugtenberg BJJ, Kijne JW (1989) Root lectin as a determinant of host-plant specificity in the Rhizobium-legume symbiosis. Nature 338:579-581.

Dorland L, Van Halbeek H, Vliegenthart JFG, Lis H, Sharon N (1981) Primary structure of the carbohydrate chain of soybean agglutinin. J. Biol. Chem. 256:7708-7711.

Dubois M, Gilles KA, Hamilton JK (1956) Calorimetric method for determination of sugars and related substances. Anal. Chem. 28:350-356.

Einhoff W, Fleischmann G, Freier T, Kummer H, Rudiger H (1986) Interaction of leguminous seed lectins with seed proteins - lectins as packing aids of storage proteins. In: Bog-Hansen TC (ed), Lectins: Biology, Biochemistry, Clinical Biochemistry v. 5, pp.45-52. Textop, Hellerup (Denmark).

Etzler ME (1998) From structure to activity: new insights into the functions of legume lectins. Trends Glycosci. Glycotechnol. 10:247-255.

Gers-Barlag H, Schecher G, Kumar NS, Rudiger H (1993) Protein body membranes as binding partners of lectins. In: Van Driessche E, Franz H, Beeckmans S, Pfuller U, Kallikorm A, Bog-Hansen TC (eds.), Lectins: Biology, Biochemistry, Clinical Biochemistry v. 8, pp.97-100. Textop, Hellerup (Denmark).

Gorocica P, Lascurain R, Hemandez P, Porras F, Bouquelet S, Vázquez L, Zenteno E (1998) Isolation of the receptor for Amaranthus leucocarpus lectin from marine peritoneal macrophages. Glycoconjugate J. 15:809-814.

Laemmli UK (1970) Cleavage of structural proteins during the assemble of the bacteriophage T4. Nature 227:680-685.

March SC, Parikh I, Cuatrecasas P (1974) A simplified method for cyanogen bromide activation of agarose for affinity chromatography. Anal. Biochem. 60:149-152.

Naeem A, Khan RH, Vikram H, Akif M (2001) Purification of Cajanus cajan root lectin and its interaction with rhizobial lipopolysaccharide as studied by different spectroscopic techniques. Arch. Biochem. Biophys. 396:99-105.

Oliveira JTA, Cavada BS and Moreira RA (1991) Isolation and partial characterization of a lectin from Cratylia floribunda Mart. seeds. Rev. Bras. Bot. 14:61-66.

Peumans WJ, Barre A, Qiang H, Rougé P, Van Damme EJM (2000) Higher plants developed structurally different motifs to recognize foreign glycans. Trends Glycosci. Glycotechnol. 12:83-101.

Ramos MV, Moreira RA, Cavada BS, Oliveira JTA, Rougé P (1996a) Interaction of lectins from the sub-tribe Diocleinae with specific ligands. Rev. Bras. Fisiol. Veg. 8:193-199.

Ramos MV, Moreira RA, Oliveira JTA, Cavada BS, Rougé P (1996b) Structural similarities among Diocleinae lectins. In: Van Driessche E, Franz H, Beeckmans S, Pfuller U, Kallikorm A, Bog-Hansen TC (eds), v.11, pp.44-49, Textop, Hellerup (Denmark).

Ramos MV, Cavada BS, Mazard AM, Rougé P (2002). Interaction of Diocleinae lectins with glycoproteins based in surface plasmon resonance. Mem. Inst. Oswaldo Cruz 97:275-279.

Rudiger H, Schecher (1993) The protein body membrane of soybean seeds as a possible lectin-binding component. In: Van Driessche E, Franz H, Beeckmans S, Pfuller U, Kallikorm A, Bog-Hansen TC (eds) Lectins: Biology, Biochemistry, Clinical Biochemistry v. 8, pp.101-104. Textop, Hellerup (Denmark).

Rudiger H, Siebert HS, Solís D, Barbero JJ, Romero A, Von der Lieth CW, Maurino TD, Gabius HJ (2000) Medical chemistry based on the sugar code: fundamentals of lectinology and experimental strategies with lectins as targets. Curr. Med. Chem. 7:389-416.

Sáez FJ, Madrid JF, Aparicio R, Leis O, Oporto B (1999) Lectin histochemical localization of $N$ - and $O$-linked oligosaccharides during the spermiogenesis of the urodele amphibian Pleurodeles waltl. Glycoconjugate J. 16:639-648.

Satoh A, Matsumoto I (1999) Analysis of interaction between lectin and carbohydrate by surface plasmon resonance. Anal. Biochem. 275:268-270.

Schercher G, Rudiger H (1994) Interaction of the soybean (Glycine max) seed lectin with components of the soybean protein body membrane. Biol. Chem. Hoppe-seyler 375:829-232.

Van Damme EJM, Peumans WJ, Barre A, Rougé P (1998). Plant lectins: a composite of several distinct families of structurally and evolutionary related proteins with diverse biological roles. Crit. Rev. Plant Sci. 17:575-692.

Wenzel M, Rudiger H (1995) Interaction of pea (Pisum sativum) lectin with pea storage proteins. J. Plant Physiol. 145:191-194.

Wu AM, Herp A, Song SC, Wu JH, Chang KSS (1995) Interaction of native and asialo rat sublingual glycoproteins with lectins. Life Sci. 57:1841-1852.

Zeng X, Murata T, Kawagishi H, Usui T, Kobayashi, K (1998) Analysis of specific interactions of synthetic glycopeptides carrying $N$-acetyllactosamine and related compounds with lectins. Carbohydr. Res. 312:209-217. 